ARTICLE

\title{
"A Flower in a Hard Rain": Melodramatic Storytelling by, and About, Aileen Wuornos
}

\author{
Suzanna Diamond \\ Youngstown State University, US \\ sdiamond@ysu.edu
}

In one of her prison letters to childhood friend, Dawn Botkins, Aileen Wuornos feigns resignation about both her impending execution and her legacy. "Like a flower in a hard rain," she claims, "I'll let things go." In fact, "letting go" of her story-at least those parts of it for which others clearly hungered-was something Wuornos ultimately would not or could not do. Instead of illumination, Wuornos's letters feature an emotionally charged pattern that has been identified as "externalization," wherein attentive members of her audience are fervently embraced only to be violently castigated. Ultimately unable to control the direction her story would take, Wuornos elected never to share it at all. Yet the heated "externalization" experts have attributed to her personality has been strangely mirrored in the ways commentators about Wuornos have approached one another.

Keywords: Aileen Wuornos; women in media; prison; letters; true crime; interview

Various tales have familiarized us with Aileen ("Lee") Carol Wuornos, a housing-insecure sex worker and multiple murderer who loitered along the abject Florida highway exit ramps in the late 1980s and early 1990s. Wuornos's life and crimes have generated a fury of storytelling adaptations. These range from tonally varied and biographical book-length "true crime" treatments such as Michael Reynolds's Dead Ends (1992), Dolores Kennedy's On a Killing Day (1994), and Sue Russell's Damsel of Death (1994) and Lethal Intent (2002), to a TV movie titled Overkill: The Aileen Wuornos Story (1992) directed by Peter Levin and starring Jean Smart. Wuornos's tale has also been treated by two feature-length documentaries, Aileen Wuornos: The Selling of a Serial Killer (1993) and Aileen: The Life and Death of a Serial Killer (2003), directed by Nick Broomfield and by Nick Broomfield and Joan Churchill, respectively. ${ }^{1}$ Perhaps the most famous iteration of this story, to date, is Patty Jenkins's feature film, Monster (2003), which won Charlize Theron the 2004 Academy Award for Best Actress. Less well-known, but contributing to this collection, is Carla Lucero's opera, Wuornos (2001), staged at the San Francisco Yerba Buena Center for the Arts. If an event's multiple adaptation signals an area of intense cultural inquiry, Wuornos's crime spree clearly represents a critical hot spot.

The kernel of fact shared by every account of this "true crime" is that in 1991, then 35-year-old Aileen Wuornos confessed on videotape to having murdered six middle-aged men whom she had lured to isolated locations near the Florida highways. ${ }^{2}$ But accounts branch out widely from this factual seed, especially when we turn to questions about the motivation or meaning of this murderous spree. To the end of her life, even the killer herself obfuscated about "what happened" by shaping her account in different ways at different times. Nevertheless, her highly emotional way of managing the discussion of these events has infected the critical discourse surrounding her. Wuornos staged a great deal of melodrama during her years of incarceration, often pitting one interviewer against others for her own purposes. But she did so based on identifiable

\footnotetext{
${ }^{1}$ Hereafter, I will refer to the 1993 documentary as Wuornos and to the 2003 film as Aileen.

2 The number, so far as we now know, was actually seven. Information about the names, ages, and murder dates of Wuornos's victims deserves coverage here; Richard Mallory, age 51, in December, 1989; David Spears, age 43, in May, 1990; Charles Carskaddon, age 40, also in May, 1990; Peter Siems, age 65, in June, 1990; Troy Burress, age 50, in July, 1990; Dick Humphries, age 56, in September, 1990; and Walter Antonio, age 62, in November, 1990.
} 
calculations about her shifting circumstances and how best to capitalize on them; her early self-representations as a "victim" or a "hero," along with her later embrace of the role of "villain," can be understood as situationally strategic. As I shall explain, however, it is more difficult to comprehend the value of these categories for commentators who have mirrored Aileen's emotionally charged rhetoric.

These ideas are layered, and they require individual unpacking; I must begin by urging skepticism towards familiar constructions of Aileen Wuornos as either a self-annihilating "hero" on behalf of one aggrieved constituency or another or, alternatively, as the blindly devoted or hapless "victim" of her faithless lover or the police. Wuornos' prison telephone transcripts and letters contradict such interpretations, outlining instead someone adept at carving situational agency out of others' fascination with her predicament.

Years into her imprisonment, Aileen might profess resignation about how her story would be told. "Like a flower in a hard rain, I'll let things go" she writes to her childhood friend and late-life pen pal, Dawn Botkins (Kester 50). ${ }^{3}$ The rain-damaged flower is a touching if not inappropriate metaphor, however, suggesting the sinking of something passive and fragile under torrents of menace or indifference. Commentators have occasionally adopted this imagery, as when Liz Randall compares Wuornos's life to a "gathering storm" that has now passed. But on her way to this eleventh hour, as her calls to Moore and her letters to Botkins underscore, Aileen comes across as anything but passive or fragile.

Russell contends that one of the things that probably most frustrated Wuornos was her ultimate lack of success in managing the story of her seven murders. "She wanted to control that, too," Russell posits, and "she grew furious when the world began going its own merry way, making assumptions about her and labeling her a man-hating serial killer in a way that didn't fit in with her version" (551). To a certain degree, this observation is insightful, but I would quibble with it in one small way; when we take into account Wuornos's telephone transcripts and, we become positioned to more fully recognize that her impulse will to govern her "story" is strangely detached from the commitment to any specific version of the harrowing events that brought her into custody. Instead, Wuornos focuses her fury on an insistence that she alone ought to profit from the narration of her tale.

As Lisa Kester and Daphne Gottlieb, the editors of Aileen's letters, explain in their Introduction, what will not be found among the executed woman's epistles is anything approaching a detailed account of the tale Russell presumes she had wished to set straight. "There are no such letters in this book," they point out.

As far as we can tell, and by her own account, Wuornos didn't write them. She couldn't. She tried. Something inside her prevented her[.] ... Call it decency. Call it blackout. Call it shame. Call it privacy, a strange sort that can only exist around murder. The exact happenings of the killings ... remained between her and her victims and went with Wuornos to her grave. ${ }^{4}$

As this implied apology underscores, even explaining why Aileen elected not to tell what happened requires speculation. Blackout, shame and privacy are not the killer's explanations for withholding details; inevitably, they are ours. Yet, whatever the barriers to disclosure might have been, Wuornos did not scruple about seducing Botkins with the pledge that eventually a full disclosure would be forthcoming. Why promise a story that would never be delivered? By sustaining suspense and cooperation, Aileen exploits the exchange value implied by Botkins's and others' assumption that she owns something. Instead of "selling" her story, Wuornos sets in motion a competitive and emotionally charged bidders' war among those who have hoped to explain her ghastly actions. In effect, Aileen franchises her possession of what others quest after in the name of her "story."

An unobserved and shrewd interactive logic is at work here. This manipulation of withheld information is visible even before the letters between Wuornos and Botkins are ever exchanged. The pattern may be witnessed, for example, in the series of post-arrest telephone calls between Wuornos and her former lover, Tyria Moore. Moore had been convinced by police to interact with Aileen in order elicit a confession from her. Reynolds posits that when Florida investigators apprehended Tyria Moore and a letter Aileen ("Lee") had written to her, they became convinced that Aileen's devotion to her lover was the key to extracting a confession. Likewise, Patty Jenkin's movie makes Aileen's videotaped confession the tragic consequence of

\footnotetext{
${ }^{3}$ Kester is the source for all references to the letters between Wuornos and Botkin. The Note, however, that the Introduction to the collected letters contains some mistaken information about Wuornos's victims.

${ }^{4}$ Page references for the letters are provided. The text's Foreword and Introduction are not paginated, however, in the digital text I reference.
} 
incautious devotion. ${ }^{5}$ These explanations do not square, however, with the tone that emerges in the transcripts of Aileen's conversations with Moore. Within these conversations, Wuornos surreptitiously gauges both her lover's continued allegiance as well as the quality of the evidence arrayed against herself; her story about what happened relents degrees of culpability that shift in a direct correlation with these perceived assets and liabilities.

Challenging later accounts that would conventionalize Wuornos's confession as a lover's self-immolation, the conversations with Moore depict an interactive confession style whereby the prisoner covertly instructs, bribes and even threatens her former partner before tentatively settling on the "self-defense" narrative that would characterize her early legal strategy. In these audiotaped calls, which took place over several days, Wuornos may be heard tenaciously brokering her way from an initial posture of complete self-exculpation through a series of compromise positions that incrementally reduce mitigation as circumstances require.

Wuornos opens this implicit plea-bidding by theatrically proposing-full knowing that Tyria knows better-that her own arrest is simply "a case of mistaken identity." Tyria can be of great assistance to her, she hints, simply by remaining quiet. "Well I don't think there's anything to worry about," Aileen says, "Just do me a favor." When Tyria asks what that favor should be, Aileen says "Just don't worry and, you know, shut. You know?" The exchange that follows highlights this wily maneuver:

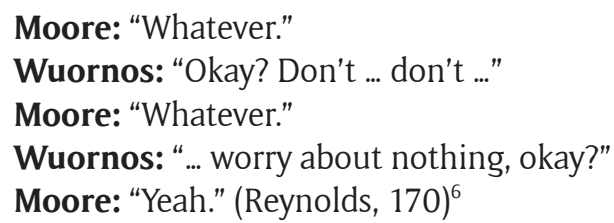

Following up Tyria's second "whatever," here, with "worry," Aileen skillfully registers her lover's refusal to cooperate and, accordingly, disavows the potentially incriminating directions launched by the first part of her interrupted sentence. "Don't ... don't ..." is thus revised into "don't worry." In a similar manner of deniable instruction, Aileen repeatedly attempts to impart exculpatory directives with locutions like "okay?," "you know?," and "right?" These hooks underscore, without directly wording, a didactic aim: to secure Tyria's verbal compliance without wording a direct request for it.

As the calls continue, Aileen's version of events nimbly adjusts itself to Tyria's responses. Since Tyria and Aileen had been witnessed in connection with a recent car accident (involving the vehicle of murder victim Peter Siems [whose body was never recovered]), police sketches of the two women had surfaced on the news; this understandably terrified Tyria and motivated her to flee from Florida. To accommodate this lingering anxiety, Aileen proposes a story aimed at reducing Tyria's anxiety about personal exposure. Thus, when Ty makes alarmingly direct references to the "car we wrecked," Aileen swiftly supplies a fictional alibi:

Wuornos: "Remember those two guys? Those ... two guys that picked us up?"

Moore: "No."

Wuornos: "Honey. (emphatically) Remember those two guys that picked us up?"

Moore: "Nooooo, I don't."

Wuornos: "Oh God. I'll bet you ten bucks you got somebody sittin there and you got a little tape recorder and you're tryin' to pin me with this shit. Just tell me right now. Do you think you would pin me with this shit?" (178)

Astutely connecting Tyria's obtuseness to her cooperation with police, Aileen illustrates not only a cleareyed openness about Tyria's possible duplicity but also, less obviously, an impulse to prioritize her own best interests ahead of her former lover's, if necessary. This becomes most clear when Aileen calls Tyria's attention to the storage locker whose key police had confiscated when they arrested her. Bringing up this issue effectively check-mates Tyria's reference to the wrecked car, slyly reminding Tyria of her own culpability and implying a quid-pro-quo arrangement in a manner that would mark Wuornos's later dealings with others.

\footnotetext{
${ }^{5}$ Patty Jenkins's Monster offers occasional glimpses of this more opportunistic side of Aileen. One light-handed example occurs when Selby flatly refuses Aileen's sidling attempt to seek money from Selby's father.

${ }^{6}$ Hereafter, Reynolds is the source for references to phone conversations between Wuornos and Moore. I will include page references without repeating his name.
} 
Wuornos: I have these two crystal balls. I mean, really pretty little crystal balls ... in that storage? If you wanna go and get'em, just take a hacksaw and open it up and get what you want outta there. Okay? And you know that ... water ... water pistol I have?

Moore: [chuckles]

Wuornos: I gave that away (181).

Given Aileen's (warranted) suspicion that her calls with Tyria are being monitored, the strategy here is worth underscoring. In the first place, Aileen's reference to the storage locker pushes back against Tyria's unilaterally incriminating earlier question about the wrecked car; it arguably provokes Tyria into re-examining the costs and benefits of cooperating with the police. Reflecting on that locker (which, unknown to both women, had been ransacked by police on the previous day), Tyria would be forced to recall that it contained items that compromised both women's claims of innocence. ${ }^{7}$ This awareness, in turn, might embolden Tyria to throw in her lot with Aileen rather than conspire against her, since Tyria was the lynchpin for the entire case against Aileen at this point. (In both Reynolds's account and Overkill, police acknowledge that they need Aileen's confession to secure a conviction; the likelihood that Tyria could have been prosecuted for her role in the crimes without it was at least equally remote.) Here Aileen is playing chess and not just checkers, as the saying goes; assuming that these phone calls were on the level and that Tyria were not collaborating with police, for example, Aileen's reference to the storage locker functions as an oblique bribe: in exchange for destroying these lingering items of evidence, Ty is invited to share in the haul. Assuming, on the other hand, that Tyria is helping law enforcement, the reminder of her own culpability functions as a veiled threat. These allusions to the storage locker are highly strategic carrot-and-stick approaches to Tyria; they serve simultaneously as a bid for continued silence and a hint to destroy evidence.

An even less obvious feature of this ploy, however is Aileen's self-serving willingness to put her former lover's liberty at risk. At least one of the items Aileen invites Tyria to take is an "eagle blanket" later determined by police to have belonged to Charles Carskaddon, one of Aileen's victims (Reynolds 181). Had things played out differently and Tyria succumbed to Aileen's directions in any of the manners hinted at-by claiming to have been "picked up by two guys," or else by pleading ignorance about, or actually emptying, the storage unit, for instance-she herself would almost certainly have hazarded prosecution, too. In short, Aileen's attempts to test Tyria's truthfulness and/or manipulate her cooperation convey that until she had no other choice except to confess, she could have countenanced taking her former lover down with her. The impression is a far cry from blind devotion.

By the time Aileen relents to confess to the murders, a plea-bargaining stance continues to mark her tone:

Wuornos: “... I'm not gonna let you go to jail. Listen, if I have to confess, I will.”

Moore: "Lee, why in the hell did you do this?"

Wuornos: "Huh?"

Moore: "Why did you do this?"

Wuornos: “Ty, listen to me. I don't know what to say, but all I can say is self-defense. All right? All I

can say is that, all right? Did you hear me?" (187)

Having carefully taken the measure of how significantly the evidence and this key witness weigh against her, Aileen confesses not out of heroism but instead out of bitter resignation. "All right?" is a signal for Moore to consent to the caveat of a self-defense plea. "Yes, I'm gonna take care of it," Aileen assures Tyria, as she urges her to return to Ohio from Florida; perceptively, she adds "I know you came down here for me to do that, right?" (192). Reynolds suggests that even the police perceived the layered purposes behind these telephone conversations. He quotes Investigator Munster's suspicion that the prisoner had been all the while "laying some shit down for our benefit, just in case" (180). In fact, so revisionary were Aileen's variations on what happened at this initial stage that, when prosecutors were first confronted with the fact that Wuornos's videotaped confession had been leaked to the press, they are said to have quipped "which one?"

Written between her first conviction in 1991 and her eventual execution in 2002, Wuornos's prison letters to childhood friend and former neighbor, Dawn Botkins, display a similarly circumstance-driven management over her account of the murders. Paul Lomartire persuasively appraises these letters as a "a chilling mix

\footnotetext{
${ }^{7}$ According to Reynolds, a driver's license receipt for Tyria Moore and a gold heart with the name "Tyria" engraved on it are two items among the storage locker's contents; he posits that additional items within the locker would have likely contained a number both women's fingerprints.
} 
of lucidity and lunacy, of girlish lingo ... and brutal confessions." The first part of this description is apt to a certain degree; the letters are indeed loaded with stories that would not be out of place in letters exchanged by high-schoolers. Standard "confessions" of homicide, however, they emphatically are not. The letters, like the phone call with Moore, clearly leverage Botkins's advocacy and unpaid public relations assistance-both which Wuornos desperately needed until the final months of this eleven year period-against Aileen's indefinitely deferred promise of full disclosure about exactly how and why the murders took place.

Given the absence of reply letters from Botkins, a reader is somewhat forced to speculate about the interactive nature of this communication, but Aileen's side of the correspondence suggests that Botkins consistently pressed for details about the murders and that this pressure was just as consistently encouraged and delayed until ultimately rebuffed by the prisoner. Aileen often cajoles her reader in these letters: sometimes lectures her and occasionally even threatens her. But the dangled promise of full disclosure about the crimes clearly keeps the letters flowing both ways. On March 13, 2001, for instance, Wuornos teases Botkins with both the suspense and the monetary value of the murder tales she intends eventually to share with her exclusively. Referencing an earlier letter, she promises that:

“... I stated in the 6 pager that I'd send on how the 7 died. Well I'm working on this now So once its sent keep in a real safe place. This will be far more worth then any of the other material you've ever recieved on Jacky and the Cops etc. So please keep it in a good safe place. It'll sent as soon as its done. 7 different incidence's" (292). ${ }^{8}$

On May 21 of the same year, the tone of Wuornos's writing continues to address and sustain the oblique pressure. She writes

"Now you asked an imperative ... and so what I'll do is send you a Kite real soon - on the 7 - In short detail ... I realize it would'nt be right to give you all that info - yet leave this out. So - yeah - I'll turn it on to ya next week. okee doke" (297-298).

Later in that year, however, as the clock is ticking towards Aileen's eventual execution, apparently Botkins presses for a visit to her imprisoned friend; by this point, Wuornos begins to shed the kid gloves of earlier exchanges and give way to overt hostility. Wuornos writes on December 26, 2001, to say that

I'm gonna tell ya right now I'm not up to having anyone visit me until the X [execution]!. "Bottom line." I'm looking for my space now, having become quite tired with visits or anything else. So sorry Dawn, but "NO WAY." ... So you'll need to get the tickets reimbursed or use them for your own Vacation down here. But you cant see me., wont let you or anybody else! To many problems with staff. And besides I just seen ya weeks ago. 12 hours that should have been good enough. Geeeeeeez., Anyway!. Sorry but it's the way I feel. Only media can get through now (314).

By this point in their correspondence, Botkins has served Wuornos in every capacity from press agent to personal shopper. In the process, she has been diagnosed with Multiple Sclerosis, has lost her mother, has had a breast cancer scare, and has raised several children. All these services notwithstanding, they will not be repaid with a confession: with "only the media can get through now," Botkins is instructed that others will record the final story. If that first letter is only cool, however, the hostility in one that follows eleven days later is unmistakable. In this letter, Aileen enforces her earlier indifference with overt aggression:

Listen up, and this - is - for real. I'm tired of pussyfootin with you and beating around the bush in a round about way to be kind and say "NO" ... don't ever think you could force yourself on me!. The day you do - your out! I won't put up with such shit for a minute!. So don't be thinking I'm some mentally unstable child that you can act like a Mother on!. I'm 45 going on 46 and will act every bit of it and more if need be!. So I'm here to tell you in all my Womenhood - buddy - that I won't allow it. Not here.... anymore (314-315). ${ }^{9}$

\footnotetext{
8 "Jackie" is Jacky Giroux, a writer, director, actress, and film producer who secured a contract with Wuornos for the rights to her story just weeks after her arrest. Additionally, as evidenced here, most of Wuornos's letters display mechanical and grammatical irregularities. Hereafter, her written language will be recorded exactly it appears in the original letters.

${ }^{9}$ All underlines in this essay appear in Wuornos's letters.
} 
Botkins's discernible pressure for the full story persists, but she is finally rebuffed in an April 21, 2002, letter that encloses Wuornos's November, 2001, letter to the Florida Supreme Court and underscores her new first-degree version of Mallory's murder; in this letter, when Wuornos asks whether Botkins received previous correspondence detailing "the road stuff," her teenage hitchhiking experiences in Indiana, Wuornos anticipates her interlocutor's pressure for more pertinent material. By this point, however, earlier promises are clearly broken for good:

And o god I can hear ya now. Why not on the Killings!?. As the answer is still - No. Everybody knows I did it and that they died, so why write ABOUT just HOW the bullet went in and they dropped dead.... And then I'll be dam if I'm going to get into anything like that'll get me depressed to, on my way out!. No Way. So thats another reason I'm sticking to the road stuff 16 up ... (323). ${ }^{10}$

In their pattern of interaction with Botkins, Aileen's letters prefigure a striking sequence whereby a number of persons seeking direct knowledge of the murderer's fateful actions gets initially embraced by Wuornos only to be later just as enthusiastically castigated and marginalized: first, like Botkins, lauded as her saviors and later discarded (though not always permanently) once drained of their perceived utility. In her Foreword to Aileen's collected letters, Phyllis Chesler traces this patterns within her own dealings with Wuornos. Recalling her phone calls and a visit to Aileen in prison, Chesler asks Aileen to:

Remember how you tried to hire me as your agent/manager ... and actually ordered me to start selling your same life story over and over again-as if you were selling sex and I was your pimp? Remember how hard it was for you to understand that I was "in it" for political reasons, not for money? or fame? (Kester)

Reeling from subsequent treatment by Aileen, Chesler adds: "I know you told people that I, too, had disappointed and betrayed you, that I was into you for the money or the fame. That hurt." While easy to dismiss as "insane" or "evil" behavior, Aileen's opportunist pattern of embracing, using, and then discarding empathetic others can be understood relationally; it is unwittingly perpetuated by the perfect coincidence between her own abjection and her cynical perception of others' hunger for the story they presumed she owned.

Nick Broomfield comes in for some of the worst of this up-and-down treatment. After his 1993 documentary, Wuornos, she celebrates him as a hero. In an April 2, 1994, letter to Botkins, the prisoner explains that "I finally wrote to Nick, ... [t]o thank him in the greatest way." In a characteristic manner, she implies that one of the "greatest ways" to express gratitude is by reciprocating in trade; therefore, she adds, she had mentioned that "if he'd ever like to interview me again. He could $3 / 44$ free" (89). At first, it would appear that Wuornos credits Broomfield's first documentary for its vindicating accuracy. His value, like Moore's or Botkins's, however, proves to be purely transactional as things play out. In a letter dated March 5, 1994, she tells Botkins that "since Nick's documentary ... I am finally getting the break I need" (84). In hindsight, one rich payoff from Broomfield's first documentary was in how it provided Aileen with a salient counter-narrative to the earlier "serial killer" formulations Russell says she strenuously objected to; this more elaborate narrative of police victimization and heroic resistance was one whose basic structure Aileen would return to intermittently until the day of her execution. Given the frenzy of mendacity Wuornos exposes, moreover, there is an irony about Aileen's offer of free coverage for Nick that appears to escape her; but her initial mood of largesse towards the documentarist instantiates a triangulation pattern that would repeat itself in other letters to Botkins.

Aileen's offer of a subsequent interview " 4 free," like a number of her short-lived honeymoons with interlocutors, serves the dual purpose of pitting those who are "in" against those who are "out." At the free interview stage, Broomfield is "in." While simply generous on its face, for instance, giving Broomfield free

\footnotetext{
${ }^{10}$ Another interesting feature of the letters-and also of interviews Aileen gave Broomfield-is her sustained interest in-and ambivalence towards-Tyria Moore; in fact, the references to Moore are frequent enough to merit a separate study. In the letters, Wuornos constantly seeks updates about Tyria, professing to wish her former partner well even while disparaging her appearance. Russell reports that Wuornos often made cruel references to Moore's looks, referring to her lover in private as "butt face." Of all the figures against whom Aileen might nurse a grudge, Tyria would seem to figure prominently, but aside from half-heartedly blaming her for money-hunger (a charge virtually nobody in Aileen's world escaped) Aileen generally abstains from assaults on Tyria's character. In her cross-examination for the Mallory trial, for instance, when Tanner tries to pursue Aileen's hint that Tyria knows more than she's saying, the defendant backs away from this vague allegation and simply answers that "she knows it was self-defense." Moore represents a remarkable site of steady loyalty from Wuornos.
} 
access enacts a passive-aggressive swipe against two of the primary targets of Broomfield's first documentary, former allies in Aileen's constellation: Arlene Pralle, the Christian horse breeder, who emerged after seeing Wuornos on television and "adopted" her in order to visit her in prison, and Steven Glazer, the visibly inept attorney known as "Doctor Legal" (occasionally denigrated as "Doctor Lethal," Russell says), whom Pralle hired to replace Wuornos's public defenders and who prompted Wuornos to plead guilty. As outlined in the first documentary, these two figures had imposed steep fees on Broomfield for access to the prisoner. Aileen's offer of free access, therefore, undercuts these erstwhile agents "out" and deprives them of their presumable share of the interview's profits. During this brief period, Broomfield is thus embraced as new ally; the fact that two former heroes are repositioned as villains by this embrace is a central feature of it, not a bug.

By March 9, 2000, however, Broomfield's stock, in turn, appears to have dipped with Aileen, who exclaims, in a domineering tone that often characterizes her exchanges with Botkin, that "I need to once again explain to you about CCR and Nick Broomfield. ${ }^{11}$ I HATE them both. And a serious hatred. So please if you would quit giving them info over the phone. Just hang up on these son of a bitches" (266). Although Broomfield's first film seems well-meaning in its impulse to expose others' exploitation of Wuornos, by this point he appears to have lost his luster, too: Wuornos charges that, among other things, he has incorrectly identified the culprits in her victim narrative. Instead of Pralle and Glazer, Wuornos now conjures a wide-ranging and less tangible set of targets: "The system itself. 'The Cops.' 'Judge.' 'prosecutors.' 'Public defenders.' 'psychologist.' 'Witness's'” (266). Pointedly, in this revised framing, Broomfield, too, becomes redefined as part and parcel of the greedy pack Wuornos sees surrounding her case; it galls her "to think how much money Nick has made off that fuckin lieing clip!" Now, she categorically commands Botkins to "Quit talking to these real low life son of a bitches!." Broomfield's relationship with Wuornos would appear to have come to an end by March 21, when she tells Botkins she had "let him know I'll never allow him to interview me ever again. Because of what he did with the $1^{\text {st }}$ one. So you probably wont hear from him anymore. Chuckle. Chuckle" (271).

Psychological experts characterized Wuornos as, in many ways, "a primitive child," and they say "never" and "always" are children's words. By May 15, 2000, Aileen appears to be revisiting her earlier resolution to sever ties permanently with Broomfield. She writes Botkins to concede that she might reconsider past "never evers," assuming the price were right:

About Nick's offer for an interview. As much as I dispise the jerk. You see I'd allow one if only hed give you 6 [thousand] up front first. Cant be any other way. 6 up front first - then make arrangements after you've got it in your mits. If he's interested. OK (274). ${ }^{12}$

And there is more Broomfield can provide. Ten months later, on March 18, 2001, Wuornos writes to add another idea; she has been "thinking about 'Nick'" in connection with her desire to secure an attorney who will help her sue the prison. Proposing a downright ghoulish bargain, in this exchange, Wuornos suggests that if Broomfield would help with attorney hiring, "I'll give him all the free air time he'd like - if he would ... I'll also see Nick right up to the X [execution]. And he can film that to - Cooool with me. Alright!" (293).

One imagines that Broomfield's response to this new offer must have lacked the desired swiftness or enthusiasm; by March 25, Wuornos ups the ante further, insisting that, although she'll "cross my fingers Nick comes through," she will now impose an expiration date on her offer of exclusive execution coverage. She directs Botkins to tell him that "if I dont hear anything this Month ... its to the Media" (294). As previously discussed, this is exactly the supplanting formula Aileen threatened in her eventual dismissal of Botkins's quest for a confession. This time, Broomfield becomes the object of a similar threat. It is unclear what has transpired behind the scenes between Broomfield and Wuornos at this stage, regarding whether he had recruited an attorney again, as requested, to facilitate the waiving of further appeals, or he had ponied up the requisite $\$ 6,000$ up front for Botkins. ${ }^{13}$ He has, by this point, apparently funded a visit between the pen pals and he is clearly back in Aileen's good graces by July 31, 2001, when she thanks Botkins for coming to

\footnotetext{
${ }^{11}$ The "CCR" Aileen refers to is the Capital Collateral Regional Counsel, a state-funded Florida agency that handles the appeal of capital sentences.

${ }^{12}$ The exchange rates Wuornos proposed for her confession range wildly. At one point, she tells "Doctor Legal," Steven Glazer, that Botkins ought to receive $\$ 100,000$ in connection with any book or movie deal about her; at another point, she offers to provide a detailed account of the murders in exchange merely for the right of Death Row women to smoke in their cells. See Kester's Introduction.

13 In 1996, Wuornos interacted with Tony Alexander, a British attorney with whom Broomfield had connected her. By March of 1997, however, she reports to Dawn that she no longer wants anything to do with Alexander; she makes another derogatory reference to him on May 2, 2001. It is unclear whether Broomfield hired another attorney for her at any later point.
} 
see her "and dear Nick in arranging it all - so you could." Of Broomfield, she says "Man. What a beautiful soul. A!?" Her proverbial right arm of ten years (by that point) gets praised in an afterthought: "And you too!" (303).

Much later, of course, as Aileen dramatizes in 2003, Wuornos abruptly retreats from earlier versions of her victimization, now telling the story of the seven murders as premeditated crimes motivated strictly by money. Looking uncharacteristically placid in an interview included in Broomfield and Churchill's documentary, Wuornos undercuts any notion that she's been wronged by police and she even appears to take a measure of mischievous satisfaction in the documentarist's clearly crestfallen line of questioning:

Wuornos: "Yeah Richard Mallory is definitely ... was not self-defense. Richard Mallory I killed in ... for ... he had an ex-I needed his wheels to move the stuff and he had the right amount of money I needed to ... move into the apartment, so ...."

Broomfield: "But what about the testimony that you gave in court?"

Wuornos: "Well that's just, like I'm saying ..."

Broomfield: "About the Visine, and ..."

Wuornos: "Oh I was just doing lying biz. That was just my lying gig trying to beat the system."

Broomfield: "Really"

Wuornos: [nods]

Broomfield: "So that was really all ... none of it was true?" 14

One obviously wishes that Broomfield could have relinquished his investment in Aileen's earlier victim story sufficiently to permit this later interview to follow where Aileen's unusually calm and lucid mood might otherwise have led it. Instead, his own visible disappointment predominates; this is a lamentably lost opportunity, and a feature of their interpersonal dynamic that is not lost on Aileen herself. Before Aileen, was released, for example, her complaint to Botkins takes a lucid measure of what went wrong in the interview. On May 15, 2002, she writes

$\mathrm{Hi}$-- the interview went., Well let me put it like this - fkd. I was so dam mad and couldn't get through. Nick kept interrupting "focused" only on his questions and how he wanted this whole thing to turn out his way so planned before hand--While same with me. So we butttt heads (325).

David Denby appears to foreclose on the possibility that any interview strategy exists that could have dug something more authentic than rants out of Wuornos; he writes that "[t]he real Wuornos is too will-driven to show us more than one side of herself." By now, the question is clearly moot, but at the time it hardly seemed like a foregone conclusion. Affirming the obstacle Broomfield's strategy itself generates, Aileen tells Botkins that she's

Sorry about Nick, but I just wasn't up to him, and was getting pissed when he kept interrupting ... so needless to say I went off in all my depression. And then ... wasn't nice about 'Anything!' Again--I'm sorry ... but I just had enough of it all (325).

Chesler, Botkins, and Broomfield are far from alone in this alternating pattern of embrace and later castigation. At various points in her letters, Wuornos idealizes-only to later demonize-a number of the people who attempt to treat her sympathetically: these heroes-turned-villains include her succession of public defenders (fired, one by one), and Pralle (whom Wuornos's letters eventually satirize in passing as "Mommy Dearest"). Wuornos signs a contract with filmmaker, Jackie Giroux, who had agreed to fund the prisoner's commissary account to the tune of $\$ 60$ per month in connection with access to her story. Giroux's investment never paid off; she never managed to market a story, but in 1991, she complained in a segment on Geraldo Rivera's Now It Can Be Told that then-President of CBS, Jeff Sagansky, told her that a signed deal with police had already been worked out. Although no corroborating evidence has surfaced, Giroux maintains that Sagansky rejected her proposal for a treatment of Aileen's case, telling her "[t]hat script's done already. It's a two-hour movie of the week; we're not fond of it, but we have a lot of money invested in the story." The

\footnotetext{
${ }^{14}$ Reviewing Broomfield's interviews with Wuornos in Aileen (2003), Denby proposes that Aileen is "determined to make her death mean what she wants it to mean, and not what anyone else wants it to." I am fundamentally questioning whether Aileen assigns "meaning" to either her crimes or her sentence in any familiar sense of the term.
} 
script Giroux references likely had no cooperation from Aileen; nevertheless, in the final analysis, it's fair to say Giroux got fleeced. ${ }^{15}$

When filmmaker Patty Jenkins comes onto the scene, Aileen characteristically views her as instrumental in kicking off Giroux. She constructs Jenkins, at least for a while, as Giroux's replacement and even hints at her awareness that the two authors function in mere succession to one another. Breezily, her April 24, 2002, letter introduces "this gal who contacted me from California."

What it is, is that she'd like to do a movie on me ... and even if it's Jackie [Giroux] with another name she's using under my nose I could careless. But what I do care about is if she could help you and I ... So my friend - exspect a call from a gal-named Patty Jenkins (323).

By this point, at least in terms of attorney procurement, Patty Jenkins shows promise, not only as Giroux's replacement but also as Broomfield's. By May 30, Aileen writes to Botkins "And don't worry about an attorney ... It looks as if the Jenkins chick is gonna take care of it" (326). After not too long, the predictable pattern renews itself and Jenkins's usefulness, too, appears to have faded; by September 23, Botkins is informed that "that Patty chick wrote again." Aileen says she is enclosing a copy of Jenkins's letter, and her description of it confirms that yet another correspondent has lost her luster:

surely anyone can read between the lines of this bitches intentions, whose definetly just after the money - off these cases. I cant believe the nerve of her, to actually state in the kite that she's gonna let the world know the truth. O yeah! And how ya - gonna do that, when I "NEVER" told ya any of it!. She's received nothing from me!. All her info's coming then from books. etc.... Unbelievable A. Then of all things - trying to obtain "a visit" ... in time enough together to write this script. "Crazy!." Isn't it something how people with money, how crazy they act behind it! (335) ${ }^{16}$

Enemies and advocates alike have grappled with the complicated "interests" represented by Wuornos's plight, but I think each has somewhat mistaken the way Aileen construed the currency function of her storytelling. Her constant revisions have invited readers to impute motives of various kinds to the killer. Was her insistence on "self-defense" reducible to some wily bid to sell copy? Was it, on the contrary, an unwitting articulation of the rage underlying women's cultural predicament more generally? Prosecutor John Tanner advances the former position; in his testimony at one of Aileen's sentencing hearings, he alleges a publishing incentive. In a sarcastic tone, he undermines the mitigation-by-self-defense narrative by proposing:

Wouldn't it be ... a much more sellable story if this poor pitiful prostitute ... was simply doing her job and some guy does horrible things to her-she killed him in self-defense? Now that's a good story.... And then her girlfriend who knew all about it got on the stand and told the jury how it was self-defense. How when Aileen came in she had bruises on her neck-she could hardly talk, he had almost choked her-and had been beaten brutally ... and that there was blood on her clothes and that this was a terrible thing.

When you add tales of abuse by the state of Florida to this drama of victimization, he sneers, "That would sell a lot of books" (Russell 461).

Just as vehemently, in opposition to this approach, Carla Lucero sees in Aileen's murders an act of karmic reprisal for the subjugation of all women: "On a karmic level," Lucero argues,

it's almost like-and many women would agree with me-Wow! I'm surprised this didn't happen sooner. I don't really condone killing, but you do have to wonder, why did this take so long? I've always likened it to a boiling pot, and [Aileen Wuornos is] the steam that escaped the pot (Guthmann).

Interestingly, both Tanner's and Lucero's interpretations-Aileen as the villainous bookseller, on the one hand, or Aileen as the instrument of heroic reprisal, on the other-share one critically important feature:

\footnotetext{
${ }^{15}$ The script Giroux references was to become the largely forgettable TV movie, Overkill.

${ }^{16}$ Wuornos's indignation about Patty Jenkins's aim to tell her story predictably centers itself around Jenkins's neglect to secure a (paid) interview with her. This, again, betrays Wuornos's obsession with being the story's primary profiteer. It is not a demonstration of control over the story in any more abstract sense.
} 
both of these meta-narratives partake in the melodramatic plot lines at work in Aileen's own emotional language. To say this differently, it can be instructive to examine the ways our stories about Aileen Wuornos often sound an unsettling bit like Aileen. The impulses to impose on Aileen the status of victim (as evidenced by Broomfield's documentaries), as evil perpetrator (as evidenced by Tanner and Reynolds), and as unsung hero (as implied by Lucero), all imply the imposition of a melodramatically inflected story, one that conjures its own antagonists in the forms of crooked police (as in Broomfield's first documentary), a victimized public (as in Tanner's account), or an avenged constituency (as in Lucero's formulation).

Russell offers a rich observation that invites us to see ways that the metaphor of translation could enable us to step beyond the infectious melodrama surrounding Wuornos and her crimes. She notes that Wuornos

... live[d] her life governed and handicapped by an emotional language that blessedly few humans speak. And as in trying to comprehend any foreign and unfamiliar language, we must seek to unlock the mysteries, taking the clues she had handed us and making stumbling attempts at translation (546).

Both Russell and Reynolds, along with Wuornos and Aileen, incorporate a number of psychologists who point us to features of a Borderline Personality Disorder (BPD) within Aileen's behavioral patterns. It is productive to view Wuornos's storytelling strategies through the lens of this "filter of impairment," as her public defender Trisha Jenkins aptly termed it. Dr. Elizabeth McMahon, who testified for the defense and who is interviewed in Aileen, observes patterns of "externalization" in Aileen's behavior, which she defines as a pervasive perception that "everybody out there was responsible. Borderlines don't see themselves as the actor, only the reactor," McMahon notes (Russell 470). "I hate you/don't leave me," is the caricature often associated with this personal pattern, along with habits of rigid black-and-white style thinking often referred to as "splitting."

Interpersonally, splitting can manifest itself as an intense and rapid vacillation between the idealization and the demonization of others: an emotionally intensified and sometimes whiplashing set of perceptions about one's own circumstances and others' motives. Asked by the defense whether she believed Wuornos completely invented the need for a "self-defense" plea, particularly regarding Richard Mallory (the murder that preceded the next six), McMahon testifies that "what generally occurs with folks like this is that there is some truth; it may not be all, but what truth there is gets distorted." She characterized Wuornos as someone whose "emotions overwhelmed her cognition" (Russell 471).

Evidence suggests that even before the murders, Wuornos displayed tendencies to situate herself within the grandiose plot lines that accord with McMahon's characterization. Several early acquaintances interviewed by Russell corroborate that she had been obsessed, even before her notoriety, with the idea that she might one day become legendary. They recount moments in her past when Wuornos had fantasized about becoming a figure in popular lore like Ma Barker or, in her partnership with Tyria Moore, like Bonnie and Clyde; in this manner, Russell proposes, she hoped to take her rightful place among the pantheon of iconic American criminals.

While I am not interested in essentializing or diagnosing the murderer herself, or in adjudicating her case in hindsight and merely for its own sake, I suggest that Aileen's recorded interactions with would-be collaborators like Botkins, Chesler, Broomfield, Giroux, and Jenkins showcase the very traits of hyperemotionalizing observed by Aileen's psychologists and former associates; at the same time, Wuornos's treatment of her secrets also evidences a uniquely lucid and not necessarily "impaired" impulse to monetize or otherwise parlay others' investment in her presumably withheld accounts into temporary personal advantages.

That heroes, victims, and villains permeate discourse about those who even discuss cases like Aileen's suggests that the emotional pattern might be highly contagious. Aileen's style of Borderline "externalization," in the form of victim and blame language, has been mirrored by the critical meta-conversation concerning those who have taken up her story. A blogger named Slarek, for instance, responding to Wuornos, suggests that "Broomfield's documentaries have almost always been about two things-the subject itself and the process of recording it." Stephen Hunter, too, argues that in this earlier documentary Aileen "turns out to be, upon reflection, a most human and pitiful person, created by forces with which no one should have to contend" and he lumps Broomfield in with the "mercenary" crowd the documentarist purports to inveigh against. Aileen is no improvement, Hunter alleges; it is simply "other reporters' facts warmed over." Carla Meyer questions the behaviors of both Broomfield as well as Aileen's family as they appear in Aileen.

\footnotetext{
17 See Lang.
} 
Responding to the interviews that appear there, she critiques the "tepid" demeanor of Aileen's mother, Diane before going on to denigrate Broomfield's interviewing techniques: "Broomfield presents himself," Meyers argues,

as one of the killer's few advocates, but what purpose does it serve to tell Wuornos, just before her death sentence is to be carried out, that he visited her mother? The tantrum that results makes for an explosive but obviously manipulated screen moment.

In the end, Slarek declares, Aileen "deserves the six life terms she got, but she certainly deserved much better than [her attorney,] Steve Glazer, [her adoptive mother,] Arlene Pralle, [her partner,] Tyria Moore [her former lover] and Nick Broomfield." Lomartire, too, finds fault among Wuornos's purported advocates. He charges that despite the fact that "Aileen found new friends while on Death Row"-likewise indicating the likes of Glazer, Pralle, and Broomfield-

they ended up being like the mean kids in Troy, Michigan. They just wanted to use her. Even Tyria Moore rarely wrote. When the tabloid TV hosts stopped coming around with their checkbooks, and the book and movie offers dried up, so did Aileen's new friendships.

Extending a patronizing defense of Botkins, who "held out as long as she could" and "cashed in" only because "Wuornos [had] urged her [to] in her letters," Lomartire acknowledges that A\&E paid Botkins \$2500 [and presumably payed other key players included in the broadcast] to be interviewed in connection with a Biography episode on Wuornos. In a tone that seems discordant with his presumable distaste for mendacity, he complains that Botkins has earned barely a few hundred here and there as various reporters have sought interviews; sadly, he notes, these paid engagements "didn't even pay for heat, lights, utilities and groceries," as Lomartire and/or Botkins inexplicably assume they were supposed to.

The chorus of critical castigation continues. Dennis Toth, blogging for Cine-Moi in response to Wuornos, remarks that "[i]t's a circus and even Broomfield has a hard time walking the thin line between documenting and exploiting and joining the bidding melee." In the same mode of moral interrogation, John Petrakis reviews the same documentary for the Chicago Tribune; he alleges that the director's impatience with the greed he sees in Pralle and Glazer might be merely a projection rooted in the banal fact that "Nick didn't get his money's worth after paying [them] \$10,000 for what they knew about Wuornos." Waxing downright reckless, Petrakis dismisses both the subject and its coverage. He insists that by the conclusion of Wuornos, "we don't care about any of them. Not the killer, the partner, the mother, the cops, the lawyer, or even the faceless victims. They all seem equally slimy, and that includes Broomfield himself." Imputing the lowest motives to Broomfield, Petrakis charges that the documentarist "had hoped to slip into town, grab a lurid story, pass judgment ... and hop a plane back to England." Instead, "he found out that the smell of mass murder may be strong, but the stench of hypocrisy can be even stronger. Likewise, reviewing Aileen, Stella Papamichael quips that while the film's title "could fool you into thinking this documentary concerns executed lesbian serial killer Aileen Wuornos," instead it dramatizes the "gripping story of filmmaker Nick Broomfield and his intrepid quest for The Truth." Tanya Horeck concurs, employing a "circus" metaphor in her search for cultural antecedents to Broomfield's approach. Accordingly, she likens Aileen to a carnival sideshow featuring the documentarist himself more than his supposed subject, and she observes that

Broomfield's starring role ... along with his first-person voiceover, can produce [a] barker-like effect. He narrates details of her indubitably strange and tragic life, while images of Wuornos, handcuffed or shackled, are presented to us on screen (Horeck 147).

Horeck is also troubled by the tabloid and entertainment industry frenzy surrounding Wuornos. The "overt cross-promotion" and package-marketing of Jenkins's 2003 film, Monster, and Broomfield's two documentaries, she says, capitalize on sensationalistic popular constructions of Wuornos as a deviant. She observes that "if images of Wuornos as poor 'white trash' were used to vilify her in the popular press, in the filmic renditions ... they are used to generate sympathy, albeit in troubling ways" (154).

Staging moral outrage against productions of Aileen's story from a demagogic angle, John Stossel, reviews Monster and professes to be appalled by the movie's presentation of Wuornos as an avenger of injustice. "When moviegoers see the graphic rape scene," he complains, "many feel Wuornos is the victim. This has family members of the real victims unhappy." One clip Stossel selects, of Patty Jenkins and Charlize Theron 
and the "research" they did in connection with the film, presents Stossel with a clearly welcome opportunity to pepper this outrage with anti-intellectualism; "one would think," he sneers, that this research would include interviews with prosecutor, John Tanner, "who spent years investigating Wuornos and the seven men she killed. But he was not consulted." Most of the victims' families will not attend this film, he steams, ostensibly because sympathetic explorations of Wuornos are inevitably "cruel to them."

Jenkins has also attracted criticism from those who bristle at the sexism implied by hiring a traditionally beautiful starlet like Theron for the gritty main role. Writing for the New Yorker, Denby finds that Theron "seemed a commercial fantasy of beauty-say, a domestic goddess in a Life magazine ad from 1954, or a prettily drawn Breck girl." Defending herself against such charges, Jenkins remarks that "[w]ell, I looked for someone who's a professional actor, who's amazing, who looks like Aileen, and the funny thing is, they're not out there" (qtd. in Aitkenhead).

There is, of course, a spark of legitimacy in many of these charges. And, the documentaries are not innocent of the impulse to moralize, to be sure. Yet the shaming tone of this pile-on seems unfair. Being content to simply call this critical chorus "unfair," however, I would be guilty of establishing my own presumable "heroism" by wagging a heroic finger at those who have victimized other commentators. This is not my purpose at all. Instead I mean to emphasize that the tenor of such criticism is unproductive. This manner of assailing sexism, classism, voyeurism, and greed can unwittingly replicate, albeit in the garb of analysis, the drama that seemed to torment Aileen's own vacillating relationships with others. That seven men were murdered and that Aileen Wuornos killed them has never been in question; disputes about how criminal justice ought to be implemented aside, Florida law was carried out as it was constituted. At the same time, those of us engaged in quests to better understand the individual or social pathology in evidence here do a perhaps unwitting disservice to that goal when we replicate such moralistic tropes in our approaches to one another.

I will offer one case in point: As viewers familiar with Broomfield and Churchill's Aileen and its interview of Aileen just ahead of her execution might recall, Broomfield's mere mention of Aileen's mother generates a tirade from which the prisoner appears unable to extricate herself. In this state, she regresses into an earlier and long-abandoned version of her murders wherein she was a "raped woman" who sets out to "save" others. Admittedly Aileen evinces a predatory dimension in its sustained close-up shots of Aileen's anguished face, her bulging eyes, and her rapidly-fired-out words. But the filmmaker's presumable sin can also be understood in less accusatory terms: this happened to be the footage Broomfield and Churchill had at hand when it came time to edit the film, and his ill-timed mention of Wuornos's mother had yielded a failed interview.

Possibly Broomfield wagered that the topic of her mother might soften Aileen and make her more introspective. ${ }^{18}$ Such a strategy might have worked with an interviewee who was less susceptible to what professionals had phrased as "emotions that overwhelmed cognition." Such intensity might have been more subdued in an interviewee with more than one day left to live. Instead, the gambit ramped Aileen's defenses up to a fever pitch. According to Horeck, Broomfield himself has described this verbal explosion as "biblical" and he claims to find it difficult to watch (157). "I'm sorry" he calls out, as a railing Aileen retreats back into the prison's inner sanctums. Nevertheless, this failure seems more of a miscalculation than a ploy, an occasion for regret, certainly, but also perhaps for understanding rather than recrimination. The accusatory tone that swirls around not just Wuornos herself but also Glazer, Pralle, Giroux, Jenkins, Broomfield and others who at one point or another have attempted to take up this story replicates but in no way translates what Russell has aptly deemed the "emotional language" Wuornos spoke. Nobody would dispute that the murdered men were victims, that they incurred a heinous wrong, that stories about this, like any, topic inevitably miscalculate or misrepresent things in accordance with one's implied sources and sometimes inexplicable sympathies. Yet Aileen's case can remind us that we sometimes need to interrogate our own modes of discourse, the "filters of impairment" whereby we lock ourselves into melodramas that specify villains, heroes, and victims among our ranks.

Mediation theorists offer key insights about the damaging features of the recriminatory approaches I have tried to examine. Samantha Hardy, for instance, asserts that professionals in mediation have been discovering how the way we tell the story of our disputes can predetermine our possibilities for resolving them.

\footnotetext{
${ }^{18}$ Diane's affect is decidedly odd, but so is her predicament as Aileen's estranged mother. In Aileen, when she is informed that as a teenager her abandoned daughter had been sleeping in the woods, Diane replies that "I never heard Barry [Diane's brother] tell me that." Broomfield pursues with "and then she ended up hitchhiking around," to which Diane rejoins pre-emptively with "which she liked." In the final onscreen exchange, Diane asks when "the exact date" of the execution will be. To Broomfield's reply of "soon," Diane seals the interview with the narcissistic musing that "I think I'll rest better." In a later scene, Broomfield reports to Aileen that Diane had apologized, but his viewer never witnesses this apology.
} 
"[C]ertain situations," according to Hardy, "seem to invoke the telling of a particular genre of stories," and she proposes that melodramatic storytelling actually mitigates against conflict resolution (250). A story, she suggests, may be offered by disputing parties with the alternate purpose of either arriving at or foreclosing upon discursive harmony. A narrative, however, in her usage, synthesizes the stories of all parties to a given dispute in order to move participants beyond their particular deadlocks. Hardy says that a "narrative reflects the cumulative effect of separate stories as their aggregate meaning comes to light." Many conflict stories, Hardy explains, assume the generic form of melodrama, and this storying format proves remarkably resistant to resolution.

Melodramatically inflected stories, Hardy points out, "are sometimes over-dramatized and even, on occasion, sensationalistic." She observes that when disputants insist on a return to how things once were, they are striving for a futile goal that Peter Brooks has labeled "dream justice." Melodramatic indignation, she insists, is founded on "dream justice" and it operates as "an instrument of manipulation, securing blind actions instead of scrutinizing options." Melodramatic accounts of conflict, one might say, imply that disputants need to "be reasonable and do things my way." Narratives that limit themselves to a melodramatic account of situations "achieve a fictional certainty by focusing on individuals and individual action rather than on the broader societal or contextual elements of the event (the conflict) in question." I would argue that we see this "fictional certainty" at work in Stossel's implication that, by definition, sympathetic treatments of Wuornos must imply cruelty to her victims, and, again, in the kneejerk assumption that self-promotion or hypocrisy must surely fuel a documentarist's quest to understand a killer's peculiar vulnerabilities. Applying Hardy's terminology, I am proposing a narrative about how, in the act of designating villains, victims, and heroes among those who have tried to tell Aileen's story, we in the critical community, too, promulgate intensely heated but sometimes light-deficient melodramas of our own.

On topics such as murder, where claims to the emotionally-charged statuses of hero, victim, villain, and the like are contended over with peculiar ferocity, it is perhaps not surprising that the critical meta-narrative itself becomes tinged with a deadlocking blame-game. Cultures of blame, however, tend mainly to reproduce themselves. Perhaps Aileen Wuornos never told the story of her own crimes because that "story" exists mainly in the imaginations of those who hungrily sought it. Perhaps the only "story" of Aileen's crimes was that others' belief in such a possession temporarily provided her the agency life had otherwise denied her. By abjuring the Borderline-style "externalization" that experts have ascribed to Aileen herself, we might work more cooperatively to translate the "foreign and unfamiliar language" her deeds bespoke.

\section{Competing Interests}

The author has no competing interests to declare.

\section{References}

Aileen: Life and Death of a Serial Killer. Directed by Nick Broomfield and Joan Churchill, Lafayette Films, 2003.

Aileen Wuornos: The Selling of a Serial Killer. Directed by Nick Broomfield, Lafayette Films, 1993.

Aitkenhead, Decca. "The Gift of a Killer." The Guardian, 26 Mar. 2004. www.theguardian.com/film/ 2004/mar/27/features.weekend1. Accessed 8 Aug. 2018. DOI: https://doi.org/10.15358/0344-13692004-Sonderheft-2004-1

Chesler, Phyllis. Foreword. Dear Dawn: Aileen Wuornos in Her Own Words 1991-2002, edited by Lisa Kester and Daphne Gottlieb, Soft Skull Press, 2012. Digital.

Denby, David. "Killer: Two Reviews of Aileen Wuornos." The New Yorker, 26 Jan. 2004. www.newyorker.com/ magazine/2004/01/26/killer-2. Accessed 8 Aug. 2018.

Giroux, Jackie. Interview. Geraldo Rivera: Now It Can Be Told, 18 Sept. 1991. index.geraldo.com/page/nowit-can-be-told-11. Accessed 8 Aug. 2018.

Guthmann, Edward. "Killer Opera." Review of Wuornos, by Carla Lucero. The Advocate, 3 July 2001. https:// books.google.com/books?id=-mIEAAAAMBAJ\&pg=PA57\&lpg=PA57\&dq=killer+opera+guthmann+ lucero\&source=bl\&ots=BEGZx1XfQY\&sig=uQ_lvLOJhWxECRNm_5veN $1 \mathrm{hp} 5 \mathrm{TY} \& \mathrm{hl}=\mathrm{en} \& \mathrm{sa}=\mathrm{X} \& \mathrm{ved}=$ 2ahUKEwiA2-79s97cAhUnc98KHRTGAj4Q6AEwA3oECAcQAQ\#v=onepage\&q=killer\%20opera\%20 guthmann\%20lucero\&f=false. Accessed 8 Aug. 2018.

Hardy, Samantha. "Mediation and Genre." Negotiation Journal. July 2008, pp. 247-268. DOI: https://doi. org/10.1111/j.1571-9979.2008.00183.x

Horeck, Tanya. "From Documentary to Drama: Capturing Aileen Wuornos." Screen, vol. 48 no. 2, Summer 2007, pp. 141-159. DOI: https://doi.org/10.1093/screen/hjm012 
"How True is Monster?" written by John Stossel. ABC News. 13 Feb, 13 2004. abcnews.go.com/2020/ GiveMeABreak/story?id=124320\&page=1. Accessed 6 Aug. 2018.

Hunter, Stephen. "Director is the Bad Guy in Documentary About Serial Killer Aileen Wuornos." The Baltimore Sun, 3 Nov. 1994. articles.baltimoresun.com/1994-11-03/features/1994307180_1_aileen-wuornosbroomfield-serial-killer. Accessed 6 Aug. 2018.

Kennedy, Dolores. On a Killing Day: The Bizarre Story of Convicted Murderer Aileen Lee Wuornos. Spi Books, 1994.

Kester, Lisa, and Daphne Gottlieb, editors. Dear Dawn: Aileen Wuornos in Her Own Words 1991-2002. Soft Skull Press, 2012. Digital.

Lang, Andras. "Borderline Personality Organization Predicts Machiavellian Interpersonal Tactics." Personality and Individual Differences, vol. 80, 2015. pp. 28-31. DOI: https://doi.org/10.1016/j.paid.2015.02.022

Lomartire, Paul. "Aileen and Dawn: A Sisterhood Haunted by Memories and Madness." The Palm Beach Post, 29 Feb. 2004. groups.google.com/forum/\#!topic/alt.adoption/IOiB2RTAFa4. Accessed 8 Aug. 2018.

Meyers, Carla. Review of Aileen: Life and Death of a Serial Killer, by Nick Broomfield and Joan Churchill. SFGate. 30 Jan. 2004. www.sfgate.com/movies/article/FILM-CLIPS-Also-opening-today-2826792.php. Accessed 6 Aug. 2018.

Monster. Directed by Patty Jenkins, Media 8 Entertainment, 2003.

Overkill: The Aileen Wuornos Story. Directed by Peter Levin, C.M. Two Production, 1992.

Papamichael, Stella. Review of Aileen: Life and Death of a Serial Killer, by Nick Broomfield and Joan Churchill. $B B C$, 14 Nov. 2003. www.bbc.co.uk/films/2003/11/14/aileen_2003_review.shtml. Accessed 8 Aug. 2018.

Petrakis, John. "Hypocrisy Imbues Tale of Aileen Wuornos," The Chicago Tribune, 25 Mar. 1994. articles. chicagotribune.com/1994-03-25/entertainment/9403250108_1_arlene-pralle-nick-broomfield-serialkiller. Accessed 6 Aug. 2018.

Randall, Liz. "Last Call for Aileen." Orlando Weekly, 9 Dec. 2004. www.orlandoweekly.com/orlando/last-callfor-aileen/Content?oid=2264882. Accessed 6 Aug. 2018.

Reynolds, Michael. Dead Ends: The Pursuit, Conviction and Execution of Female Serial Killer Aileen Wuornos, the Damsel of Death. St. Martin's True Crime Library, 2003.

Russell, Sue. Lethal Intent: Aileen Wuornos, America's Deadliest Female Serial Killer. Pinnacle, 2002. Digital.

Slarek. "Death and the Maiden." Review of Aileen Wuornos: The Selling of a Serial Killer, by Nick Broomfield. 17 Jun. 2005. www.cineoutsider.com/reviews/dvd/a/aileen_wuornos_selling_of_serial_killer.html. Accessed 8 Aug. 2018.

Toth, Dennis. Review of Aileen Wuornos: The Selling of a Serial Killer, by Nick Broomfield Cine-Moi. 27 Feb 27 2009. cinemoireviews.blogspot.com/2009/02/aileen-wuornos-selling-of-serial-killer.html. Accessed 6 Aug. 2018.

How to cite this article: Diamond, S 2019 "A Flower in a Hard Rain": Melodramatic Storytelling by, and About, Aileen Wuornos. Anthurium, 15(2): 2, 1-14. DOI: https://doi.org/10.33596/anth.381

Published: 23 September 2019

Copyright: (c) 2019 The Author(s). This is an open-access article distributed under the terms of the Creative Commons Attribution 4.0 International License (CC-BY 4.0), which permits unrestricted use, distribution, and reproduction in any medium, provided the original author and source are credited. See http://creativecommons.org/licenses/by/4.0/. 